\title{
How Superiors' Features Can Influence Employees' Job Satisfaction -Case Study of The Metallurgical Enterprise
}

\author{
Manuela Ingaldi ${ }^{1}$ and Szymon Dziuba ${ }^{2}$ \\ ${ }^{1}$ Czestochowa University of Technology, Faculty of Management, Czestochowa, Poland \\ ${ }^{2}$ Wroclaw University of Economics, Faculty of Engineering and Economics, Wroclaw, Poland
}

Correspondence should be addressed to: Manuela Ingaldi; manuela.ingaldi@wz.pcz.pl

Received date:14 November 2019; Accepted date: 21 January 2020; Published date: 15 June2020

Academic Editor: Beata Malik-Kozłowska

Copyright (C) 2020. Manuela Ingaldi and Szymon Dziuba. Distributed under Creative Commons Attribution 4.0 International CC-BY 4.0

\begin{abstract}
The main duty of each superior is managing the enterprise. An important part of being a leader is managing people. The way a superior manages his staff and what style and personality he has, can have an impact on the employees' behavior, their work, their performance, how they feel in a given enterprise and consequently their job satisfaction. With effective leadership styles and approaches to employees, superiors create an appropriate organizational culture while employees want to be part of this culture, which should be reflected in their work performance, and thus in the profits achieved by the enterprise. A particularly important role the supervisor plays in the metallurgical enterprise where the production process is quite tough, is usually conducted in a four-shift system where the results are impossible to be corrected. The aim of this paper is to assess the characteristics of the superiors in terms of employees' opinions. The 4E+1P principles, twelve golden rules and Toyota's principles were used to indicate the superiors' features. The research had a form of a survey. The research was conducted in a chosen metallurgical enterprise. It was seen that the manager of the research enterprise made decisions solely without asking employees for advice, he did not motivate them to develop and the employees complained about the lack of job security.
\end{abstract}

Keywords: Supervisors' Features; Job Satisfaction; Survey, Employees' Opinion. 


\section{Introduction}

"A good boss makes his men realize they have more ability than they think they have so that they consistently do better work than they thought they could".

\section{Charles Erwin Wilson}

The role of the superior is not only to manage the enterprise and make decisions. The biggest challenge is to manage people, motivate them and develop an appropriate organizational culture so that the enterprise can achieve the planned goals (Kondra and Hurst, 2009). It should be noted that the leadership style and superiors' features are reflected in the behavior of the employees. They primarily affect people's commitment to work and also their job satisfaction.

Vanucci et al. (2017) claimed that management is associated with technical knowledge, interpersonal relationships, skills and work coordination, so it is a key part to achieve the organizational goal and be creative. Management is one of the techniques that make an employee happy or dissatisfied with the level of job satisfaction.

Employees' job satisfaction plays a key role in the functioning of the organization (Koys, 2001). Therefore, it is very important for the organization to understand exactly how the employee feels, what working conditions he/she has and what his/her level of satisfaction is (Murad Miah, 2018).

Employees respond, and best and most effectively act not when they are controlled by management, placed in narrowly defined positions and assessed as a necessity. On the contrary, when they receive broader responsibilities, they are encouraged to contribute in the decisionmaking process concerning the enterprise where they work and help achieve better results. People are motivated to achieve specific goals and they will be satisfied if they achieve these goals through better performance, even if these are goals of the enterprise where they work. They can be even more satisfied if they are rewarded with an external recognition or an inner sense of achievement (Armstrong, 2003). This external recognition is the responsibility of the superior.

The aim of this paper is to assess the characteristics of the superiors in terms of employees' opinions. In order to achieve this aim, a survey was conducted among employees of a chosen metallurgical enterprise who were asked to characterize their superiors. The survey allowed for an indication of the positive and negative features of the supervisor. The study was conducted in the form of a case study.

This research contributes to the existing literature on management, but at the same time it adds value because it shows how to assess job satisfaction in a quite easy way and to describe a supervisor's features. It offers a simple methodology that can be used in any type of enterprise.

It should be emphasized that this study, as well as literature analysis, were made from the point of view of engineers, not people associated with HR, which certainly has an impact on the content and the result of the study. People are an important element of the production system, which has a very large impact on the production process, and thus the final products and their quality. What is more, the metallurgical industry is very specific, it is a heavy industry, characterized by specific laws and very characteristic production, hence, this approach is presented.

\section{Literature Review}

\section{Leadership}

Constant changes taking place in the area of information, technology and economy can be observed in modern organizations. It is necessary to manage them properly in order to achieve the desired effects and regularly achieve the best possible results. Currently, the role of a manager as a 
person who inspires, motivates and encourages the employer to act is growing significantly (Czerw and Babiak, 2010, and Kotus, Koloman and Hudec, 2018). Their function, characterized by significant dynamics, is important for the development of any organization (Oliviera, Oscrivao, Nagano, Ferraudo and Rosim 2015, and Ulewicz, 2013).

As a workplace, the enterprise must take into account the specific nature of changes taking place in its environment. This applies to changes in material, technological, cultural and social conditions, which require that the way of working should be adapted to the expectations of the employees. In this context, it is particularly important for managers to ensure that employees' potentials are developed and properly managed. Organizations should use a variety of methods and tools to motivate people to make their work more effective (Sawczuk and Kurowicka, 2018). Therefore, not only the organization itself, but also its superiors are extremely important in terms of job satisfaction (Steinhardt, Dolbier, Gottlieb and McCalister, 2003). It is their methods and actions that help subordinates identify themselves with the mission and vision of the enterprise, take care of co-workers and the atmosphere of the workplace. Counteracting negative behaviors and increasing satisfaction with the duties performed is the managers' responsibility and is closely related to their preferred leadership styles (Cicero, Pierro and van Knippenberg, 2007).

Leadership style and its impact on job satisfaction are very visible. Leadership style is the basis for creating an environment where employees are happy and enjoy working (Brenninger, 2015). There are many schools that speak about the leadership styles, such as: Great man theory, Trait theory, Behaviorist theory, Situational leadership, Contigency theory, Transactional theory or Transformational theory (Bolden et al. (2003). They are described in detail in the available literature.
For example, Great man theory is the oldest theory of leadership. This theory showed that great leaders are heroic, mythical and intend to achieve leadership when necessary (Madanchian, Hussein, Noordin and Taherdoost, 2017) and (Kirkpatick and Locke 1991). According to this theory, leaders are born, not made and some individuals are superior to others. The ability to lead depends on where is this person born, his status, privileges and money power (Spector, 2015).

Trait theory (also called dispositional theory) focused on the various behavioral traits that leaders can be devoted to (Hussein, Noordin and Taherdoost, 2017). This theory is focused on discovering individual differences, but it gives up discovering personality mechanisms (Matthews, Deary and Whiteman, 2003). It categorizes features that distinguish leaders from followers and explains that some people are born with certain features that make them good leaders, so leadership is innate (Gray and Smeltzer, 1989).

Among the most popular research directions in the engineering approach, there are three basic groups: personality, situational and personality-situational (Mroziewski, 2005). There are also divisions based on a different number of criteria, including the scale of $R$. Tannenbaum and W. H. Schmidt (1958), based on one condition and listing the styles from the most autocratic to the most democratic.

However, the most popular classification is the managerial grid model developed by J. S. Mouton and R. P. Blake (Blake and Mouton, 1964), (Blake and Mouton, (1985) based on R. Likert's continuum of styles (Likert, 1967). Based on the concern for employees (vertical axis) and involvement in the appropriate performance of tasks (horizontal axis), they created a graph of the managerial behavior (Wyszkowska, Jakubczak and Doering, 2015), distinguishing five leadership styles: impoverished management (little concern for both employees and tasks), country club management (big concern for people, but little concern for tasks), produce-or- 
perish management (focus on tasks, without concern for employees), middle-ofthe-road management (finding the optimum balance between concern for people and tasks) and team management (strong commitment to the performance of tasks while taking care of subordinates' satisfaction).

Literature also provides a division of four leadership styles, which includes autocratic, participatory, democratic and laissez-faire styles (Bucurean, 2016). In the first style, the manager acts as a leader who tells his/her subordinates what to do, expecting that his/her instructions will be followed without questioning. This style works best when the tasks are simple and the contact with employees is rather short (Brahim Riđić and Jukić, 2015). The participatory style occurs when a leader engages subordinates and makes decisions together with them (Bell and Mjoli, 2013). Studies have shown that such a manager gains more respect and chooses better solutions, while at the same time influences employees' productivity (Lumbasi, K'Aol and Ouma, 2016). The manager using the democratic style attempts to follow the principles of democracy (Gastil, 1994). This style is characterized by openness, collegiality and joint decisions made with the team (Ray and Ray, 2012). Such behavior encourages employees to be creative and increases their involvement in the activities for the enterprise (Amanchukwu, Stanley and Ololube, 2015).

The French term "laissez-faire" or "let it happen" is also used to describe another leadership style. This style is characterized by avoiding decision-making (Chaudhry and Javed, 2012). Managers usually allow a high degree of independence to their employees, allowing them to decide freely about important issues concerning their work (Żuchowski, 2018, and Amanchukwu, Stanley and Ololube, 2015).

It is commonly believed in modern organizations that taking care of employees' satisfaction influences their positive behavior expected by the superior. First and foremost, employers hope that a satisfied employee will be more effective and involved at the same time (Springer, 2011). However, to a large extent, satisfaction and effective performance of the assigned tasks depend on the superiors, because, as P. Wachowiak (2001) argues, a manager must be able to influence the behaviors of the employees and be able to manage them in accordance with the intentions important for the organization.

A manager is a person responsible for coordinating activities, leading to the fulfillment of the enterprise's mission. He decides how to achieve the set goals and provides information to his subordinates (Stoner, Freeman and Gilbert, 1994). A manager both motivates and encourages employees to present their own ideas for the improvement of the enterprise and creates an integrated team responsible for various tasks. A manager achieves this, among other things, through incentives and rewards for the successful work, as well as using his own promotion policy. These actions require appropriate skills, allowing for an efficient and objective assessment of the performance of subordinates, while at the same time ensuring that their needs are met. A manager should also be able to adapt to the changing reality and cope with different situations, including responding to emerging conflicts between employees in the company. He/she has many interpersonal, informational and decisionmaking roles to perform in an organization. These roles are constantly extended and enriched. The way a manager copes with them determines whether the employees feel satisfied with their work and become more and more involved (Mintzberg, 1971).

\section{Employees' Job Satisfaction}

The employees are an essential element in the process of implementing the enterprise's mission and vision, especially in the production sphere. Employees should meet the performance criteria set by the organization to ensure the acceptable quantity and quality of their work. To achieve this, the organization should first take care of the employees and their job satisfaction in particular. High level of job satisfaction of employees often 
means a lower staff turnover rate (Scanlan and Still, 2013) and (Shen and Zhu, 2012), hence employees' high morale. Job satisfaction is one of the most studied fields of work design research in psychology (Parker, Morgeson and Johns, 2017) and (Lepold, Tanzer, Bregenzer and Jiménez 2018). Koys (2003) defines job satisfaction as the employees' perception and evaluation of the job.

Job satisfaction is the essential element for employees' motivation and stimulus towards better performance of their work. It is associated with how people perceive, think and feel about their jobs (Spector, 1997). It should be an essential aim for any organization to reach because employees are the most important production resource for any process.

Job satisfaction can be defined as a sense of employees' achievements and successes. It is generally believed that it is directly related to productivity and work performance, as well as to personal wellbeing. Job satisfaction means doing the work one likes, doing it well and being rewarded for own efforts (Kaliski, 2007). Job satisfaction should be treated as another vital work attitude (Heller and Watson, 2005) and (Ilies, Wilson and Wagner, 2009). It is usually defined as an attitude evaluating the work or the job experience.

Job satisfaction results from the requirements and expectations of the organization as well as the expectations of the employees and personal goals. Employees and their organization have mutual relations. The organization should provide employees with motives to meet a number of needs and fulfill their personal aspirations. Employees provide the organization with resources so that it can achieve its goals (Vallejo, Vallejo and Parra, 2001).

People can also have different approaches to various aspects of their work, such as the type of work they are doing, colleagues, superiors or subordinates and also their salary (George and Jones, 2008). Different motivation styles and leadership styles can work in different ways for every employee, resulting in an increased work performance and job satisfaction. Therefore, job satisfaction is an essential element which motivates employees and encourages them to achieve better results (Raziq and Maulabakhsh, 2015).

Ostroff (1992) says that employees' satisfaction is of great importance not only for the employees but also for the entire organization. Because satisfied employees are usually happy and motivated to work, consequently the organization can get amazing results from their work. On the other side, those dissatisfied employees will not be encouraged and will be disturbed by their work routine, so they will run away from responsibility and even avoid working (sick leave, days off etc.) (Judge, Thoresen, Bono and Patton, 2001).

Each person has different criteria for measuring his/her job satisfaction. The factor that influences that is the style of management, as well as payments, working hours, schedule, benefits, stress level and flexibility. Job satisfaction is related to productivity, motivation, work performance and life satisfaction (Abuhashesh, Al-Dmour and Masa'deh, 2019), which means that this also applies to the private lives of the employees

There are four determinants influencing employees' satisfaction: "supervisor/leader", "job design", "workplace environment" and "performance pay". According to the available literature, the factor "supervisor/leader" does not have a strong impact on employees' motivation but is crucial for job-design satisfaction and it very much affects the level of satisfaction with performance pay(Brenninger, 2015).

The subject literature indicates a strong correlation between employees' satisfaction and the effects of the organization's activities. Among the widely researched and verified relationships are the impact of job satisfaction on commitment to work (Shepherd and Mathews, 2000) and thus on the effectiveness (work performance), as 
presented by Yalabik, Popaitoon, Chowne, and Rayton, (2013) in their model.

\section{Methodology}

The research took the form of an easy questionnaire. It was filled in by 47 employees of the chosen metallurgical enterprise in March-April 2019. What is important is that they were subordinates to the same manager.

The research enterprise belongs to the metallurgical industry. It should be remembered that this is a very specific industry (heavy industry). In such enterprises, men are most often employed; women are rather employed only in offices and for organizational work. Therefore, this may be reflected in the results. Men have different approaches to surveys than women. Not only that, they create different bonds and different atmospheres (employee-employee and employeesupervisor) than women (her feelings and conflicts play a big role). They often have different requirements for working conditions.

The employees were asked to answer with "YES" or "NO" to the given statements about their supervisor's features, which were divided into 3 groups. This research allowed for an indication of the positive and negative features of the supervisor.

The supervisor's assessment was based on 3 following groups of statements (Konstanciak, Borkowski and Jagusiak, 2011, and Ingaldi and Dziuba, 2016):

(1) An assessment according to $4 \mathrm{E}+1 \mathrm{P}$ principles, based on 5 features: My leader $1 \mathrm{E}$ - Is full of enthusiasm all day long, 2E - Is able to encourage others to take actions, 3E - Makes decisions fast when it comes to production process, $4 \mathrm{E}$ - Knows how to implement decisions, $1 \mathrm{P}$ - Cares for the success by co-workers.

(2) An assessment according to twelve golden rules, based on 12 features: My leader $1 \mathrm{GR}$ - Sets a good example, 2GR - Communicates about goals of actions, 3GR - Informs about news in production process, 4GR - Asks staffs for advice related to correct processes, 5GR - Gives support during performance of tasks, 6GR - Directs and is demanding, 7GR - Allows to improve work independently, 8GR - Rewards for good work, 9GR - Thanks openly, 10GR - Criticizes in a discreet manner, 11GR - Forgives and encourages for achieving good results, $12 \mathrm{GR}$ - Is open to ideas by the staff.

(3) Toyota's principles, that is what leaders do?, based on 8 features: My leader 1TP - Improves work in his team, 2TP Cares if the team lives by the rolling mill's vision, 3TP - Influences with energy and positive attitude, 4TP - Is open, 5TP - Is confident while making decisions , 6TP - Cares if his questions are followed by actions, 7TP - His behavior inspires for learning, 8TP - Is success-driven.

$4 \mathrm{E}+1 \mathrm{P}$ principles (Welch and Welch, 2005) are very often used for the assessments of candidates during interviews for managerial positions. Twelve golden rules (Nickles, 1995) contain comprehensive characteristics of a person and can be successfully used during investigations. Toyota has developed leaders' features, which can also allow for revealing a number of supervisor traits (Liker, 2003; Mielczarek and Knop, 2018).

The results of the research were presented in a graphical form (bar charts). In the case of the first part, where the superior was assessed, the answers YES, NO and YES-NO were available for each of the three parts of the features.

The employees of the research enterprise were also asked to assess three items that allow to determine their job satisfaction:

\footnotetext{
- Overall satisfaction with working conditions.

- Relations with the superior.

- Satisfaction with salary.
}

Employees were asked to evaluate the above mentioned elements on a scale of 1 to 10, where 1 meant complete dissatisfaction whereas 10 meant full satisfaction. The results of this part of the 
survey are presented in the form of a bar chart, where bars indicate the average rating of an element in relation to the maximum rating that this element could obtain (satisfaction index).

The questionnaire containing the supervisor's assessment was used by authors before to analyze superiors' features in other enterprises, for example in the papers of (Ingaldi, and Dziuba, 2016). The validity of the questionnaire was established by conducting a pilot research in another enterprise.

The Cronbach Alpha test was performed for individual tools on the supervisor's assessment and satisfaction indexes to analyze the reliability of scale data. The obtained results were interpreted according to the assumptions presented by Hair et al. (2003).

\section{Results and Discussion}

\section{Cronbach Alpha test - results}

In Table 1 , the results of the Cronbach Alpha test were shown. The results are in the range (0.7-0.8), which means that the results for the individual groups of statements are good and can be further analyzed.

Table 1: Cronbach Alpha for the supervisor's assessment (own study)

\begin{tabular}{|c|c|c|}
\hline Groups of statements & Cronbach Alpha & N of items \\
\hline 4E+1P principles & 0.792 & 5 \\
\hline 12 golden rules & 0.726 & 12 \\
\hline Toyota's principles & 0.754 & 8 \\
\hline Satisfaction indexes & 0.799 & 3 \\
\hline
\end{tabular}

\section{The 4E+1P Principles - Results}

The results of the characteristics of the supervisors based on the $4 \mathrm{E}+1 \mathrm{P}$ principles are presented in Figure 1.

a)

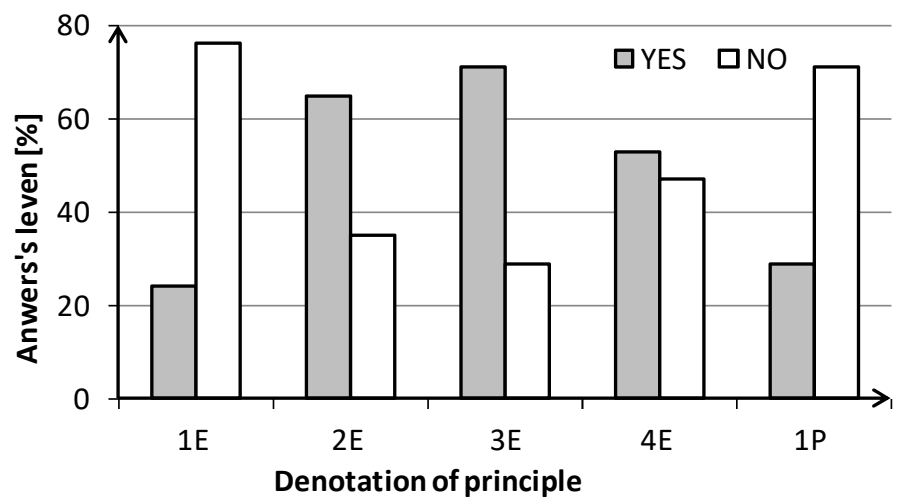


b)

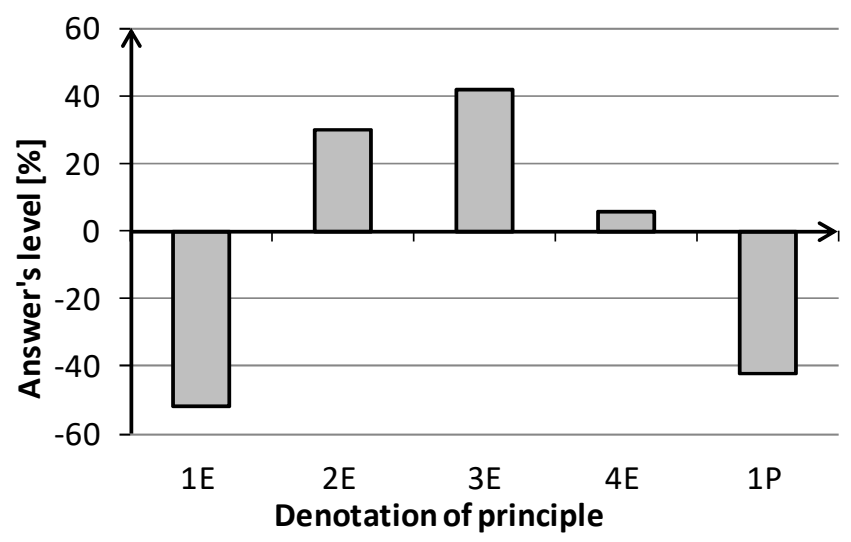

Fig. 1 : An assessment's structure according to the 4E+1P principles: a) general results (YES, NO), b) difference in answers (YES-NO) (own study).

Analyzing Figure 1 can reveal that the employees assessed the individual features of the superior in very different ways. Most of them said that their superior was able to encourage others to take actions (2E) and made decisions fast when it comes to production process (3E). These are two important features of a superior. The superiors' task is to motivate employees to act and make them willing to take up the task. A supervisor is a person who has to respond to various events and must respond very quickly, especially in situations of pressure in time. This is particularly important in the case of the metallurgical enterprises, because the situation in such enterprises is changing very dynamically; the supervisor often goes out to the production hall and works together with other employees in crisis situations..

The same employees said that unfortunately, their supervisor was not full of enthusiasm all day long (1E) and did not care for the success by co-workers (1P). In the case of these two features, the difference between positive and negative responses was negative. Such a situation should be worrying, because the superior should take care of his employees, their development and their well-being. Otherwise, it will be difficult to keep employees in the enterprise, and new employees will have to learn how to work, gain experience etc. Working in a metallurgical enterprise is not easy and great experience is needed, which is why it is so important not to let employees leave.

\section{The 12 Golden Rules - Results}

The results of the characteristics of the supervisors based on the 12 golden rules are presented in Figure 2. 
a)

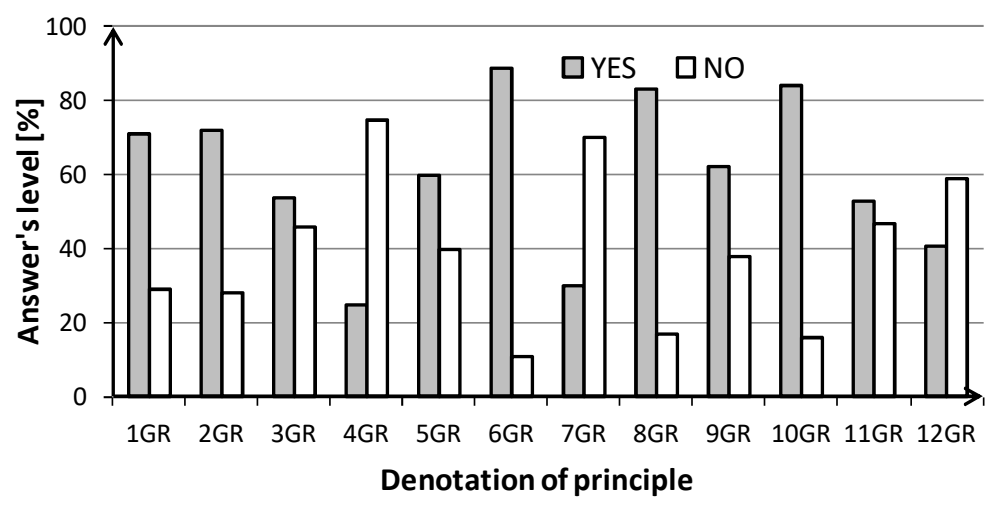

b)

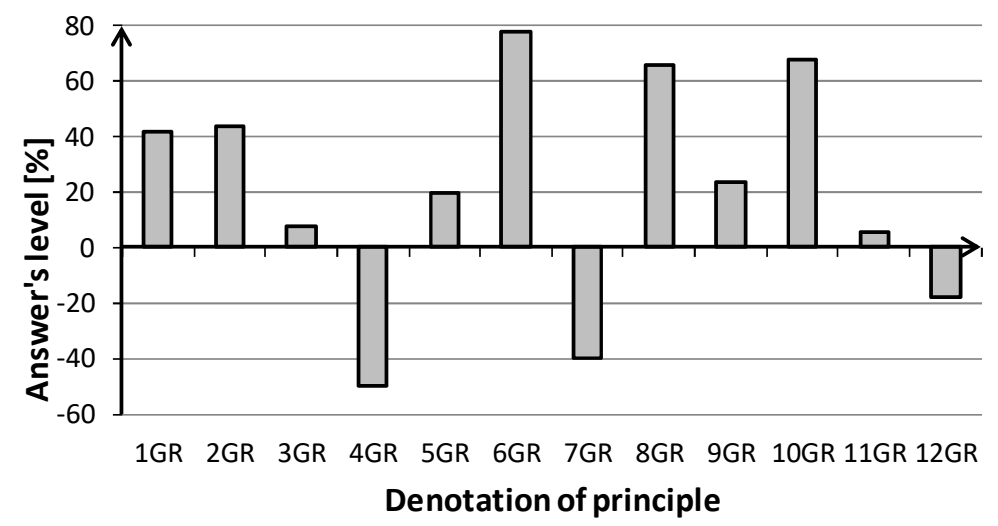

Fig. 2: An assessment's structure according to the 12 golden rules: a) general results (YES, NO), b) difference in answers (YES-NO) (own study).

In the case of the 12 golden rules, the positive features of the superior indicated by employees were: he directed and was demanding (6GR), rewarded for good work (8GR) and criticized in a discreet manner (10GR). These are important features because it is the superior who should make decisions and give instructions. Rewarding and criticizing represent an element of management. An appropriate choice of rewards and criticizing in a discreet manner are a good element in motivating employees. It is important here that the employees are mainly men. They like to solve problems among each other. They don't like hiding feelings or understatements. They prefer to have everything said, explained to clear the atmosphere of work.

On the other hand, the employees said that their superior did not ask staffs about advice related to correct processes (4GR) and did not allow to improve work independently (7GR). The superior feels like he is the one who has to decide, who introduces all the changes and the employees have to follow his instructions. The substantial majority of the negative answers were obtained for two traits. It's a pity, because older employees, with a lot of experience, could help a lot in eliminating problems and in developing the enterprise in terms of production (changes in 
equipment, its operation, defects elimination but also in the production process itself).
The results of the characteristics of the supervisors based on the Toyota's principles are presented in Figure 3.

The Toyota's Principles - Results

a)

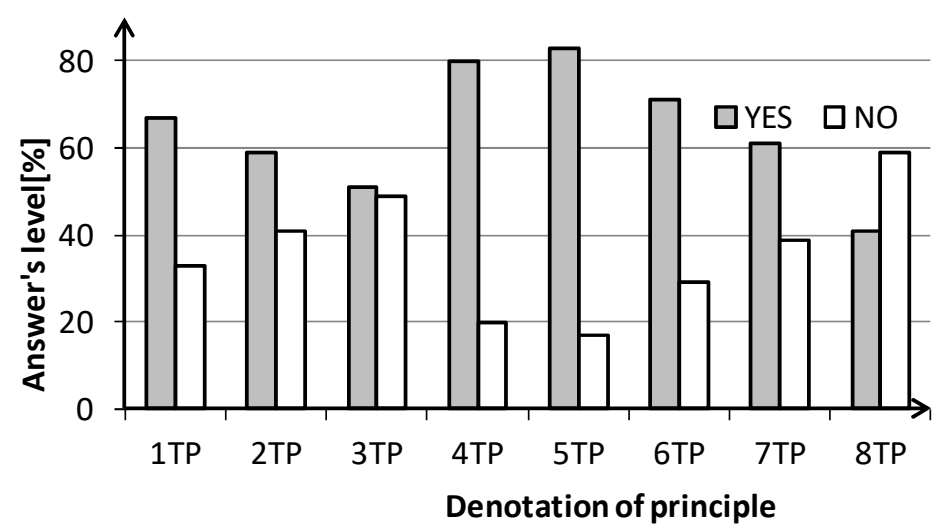

b)

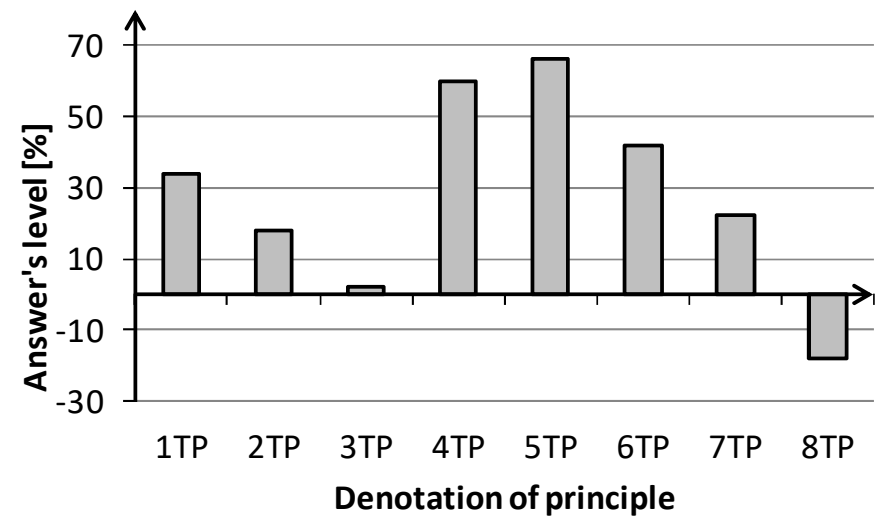

Fig. 3: An assessment's structure according to the Toyota's principles: a) general results (YES, NO), b) difference in answers (YES-NO) (own study)

In the analysis of the results concerning the Toyota's principles, it was shown that according to the employees, their superior was open (4TP) and was confident while making decisions (5TP). The second feature confirms the result obtained from the $4 \mathrm{E}+1 \mathrm{P}$ principles (trait 3E). The superior makes decisions quickly and in a confident manner and is not afraid of responsibility. The openness of the superior has a positive impact on employees' motivation. It is easier to talk to such a superior as he/she understands employees' problems. Again, the fact that the manager spends time with employees in the production hall in difficult situations is important. There, he has a direct contact with his subordinates.

Furthermore, the respondents indicated that the superior was not success-driven (8TP), which for employees, is linked to trait $1 \mathrm{P}$ (the $4 \mathrm{E}+1 \mathrm{P}$ principles). The superior does not influence the development of the employees and their opportunities for achieving success, which, unfortunately, is negative from the standpoint of motivation and maintaining employees in the enterprise. 
Satisfaction Indexes - Results
Figure 4 shows satisfaction indexes based on the ratings given by the respondents.

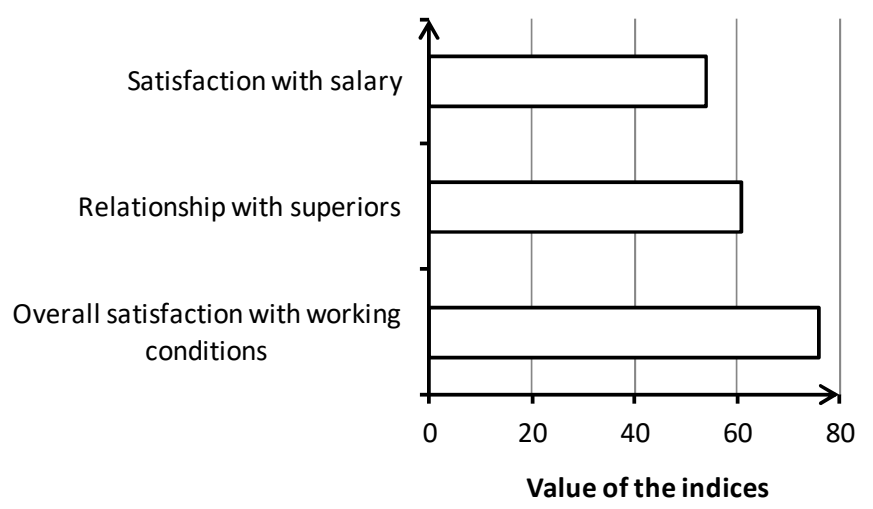

Fig. 4: Satisfaction indexes (Dziuba, Ingaldi M., Zhuravskaya, 2020)

General employees' satisfaction (mean of all three indexes) was $63.7 \%$. This is a good but not satisfactory result. Most employees are satisfied with their working conditions. The lowest level of satisfaction was found in salaries. The mean satisfaction is close to the mean assessment of relations with superiors.

This result may be due to the superior's traits that were previously analyzed, especially the negative ones. Employees are not asked for advice about the processes used in the enterprise; they do not improve them; they do not feel responsible for the enterprise, and the behavior of their superiors does not motivate them to develop themselves and strive for success. The unsatisfactory employment safety also negatively affected the general level of satisfaction. If an employee does not see his/her future in the enterprise, does not see the possibilities of his/her development and is not properly motivated, he/she will perform his/her assignments less accurately without sufficient attention. Sooner or later, they will look for a new job and the enterprise will have to look for new employees. All this leads to low work performance (Dziuba, Ingaldi M., Zhuravskaya, 2020).

\section{Summary of the Results}

Summing up, the employees described their supervisor in the surveys, indicating the following features (high predominance of answers with "YES" or "NO"). According to employees, their direct supervisor: was able to encourage others to take actions (2E), made decisions fast when it came to production process (3E), directed and was demanding (6GR), rewarded for good work (8GR), criticized in a discreet manner (10GR), was open (4TP) and was confident while making decisions (5TP). These features were positively evaluated by the respondents. But unfortunately, at the same time, their supervisor: was not full of enthusiasm all day long (1E), did not care for the success by co-workers (1P), did not ask staffs for advice related to correct processes (4GR), did not allow to improve work independently (7GR) and was not success-driven (8TP).

In conclusion, the superior uses a rather friendly autocratic style (Kożusznik, 1985). This style means that the superior expects full subordination in exchange for certain privileges, and sometimes he uses rewards for the most obedient individuals, treats employees kindly, but rarely uses their advice. The superior primarily rewards

Manuela Ingaldi and Szymon Dziuba (2020), The Journal of Organizational Management Studies, DOI: 10.5171/2020.758804 
loyalty according to the manifestation of the behaviors he/she appreciates. So there is a full subordination of employees in exchange for the privileges obtained. The incentive system is expected to inspire subordinates to seek kindness of the disposer of the desired resources. The managers give them the opportunity to express their own judgments and opinions, but make the final decisions on important issues solely.

In the case of metallurgical enterprises, the results can be approached from two extreme sides. On one hand, this approach does not allow employees to participate in production changes, which is important because they are the ones in contact with the machines and the product, and know what problems they are facing, so they can help solve them. On the other hand, due to the fact that men predominate among employees, this can cause too much loosening of the employee-supervisor relationship, so the supervisor should be very careful about that.

All the indicated features of the supervisor influence the employees who may feel that their superiors do not lead them to success, do not motivate them through participation in decision-making concerning the work or its improvement. This can, then, have an effect on their job satisfaction.

\section{Summary}

The superior and his/her features influence the organizational culture and the atmosphere in the enterprise. They play an important role in creating a working environment and providing employees with information and feedback. Consequently, the way the superior behaves towards the employees influences the affective response from the team members.

The present paper discusses the results of a questionnaire survey conducted in a metallurgical enterprise. The research concerned the characterization of the superiors of a selected group of employees. In the paper, a typical engineering approach was used due to the industry in which the research was conducted and also the engineering education background of the authors.

The most important positive and negative traits of the employee's superior were identified by means of grouped statements in accordance with the $4 \mathrm{E}+1 \mathrm{P}$ rule, 12 golden rules and the Toyota's principles. Satisfaction indexes were also calculated.

Based on the model presented by Yalabik, Popaitoon, Chowne and Rayton, (2013), literature review and the survey results, it can be emphasized that the personality of a supervisor influences the work performance, which can be presented in a graphic form. in cases of worrying situations in the team, for example conflicts, decreased effectiveness, stagnation, etc., the cause is directly or indirectly the result of a mistake that was deliberately or unconsciously made by the supervisor. A good supervisor knows how to motivate his or her employees to work. Properly instilled employee motivation enables to achieve goals more effectively, which, combined with the employee satisfaction, helps create a favorable working atmosphere and greater involvement of employees at all levels of the organization, which ultimately improves the employees' work performance (the model is shown in Figure 4). 


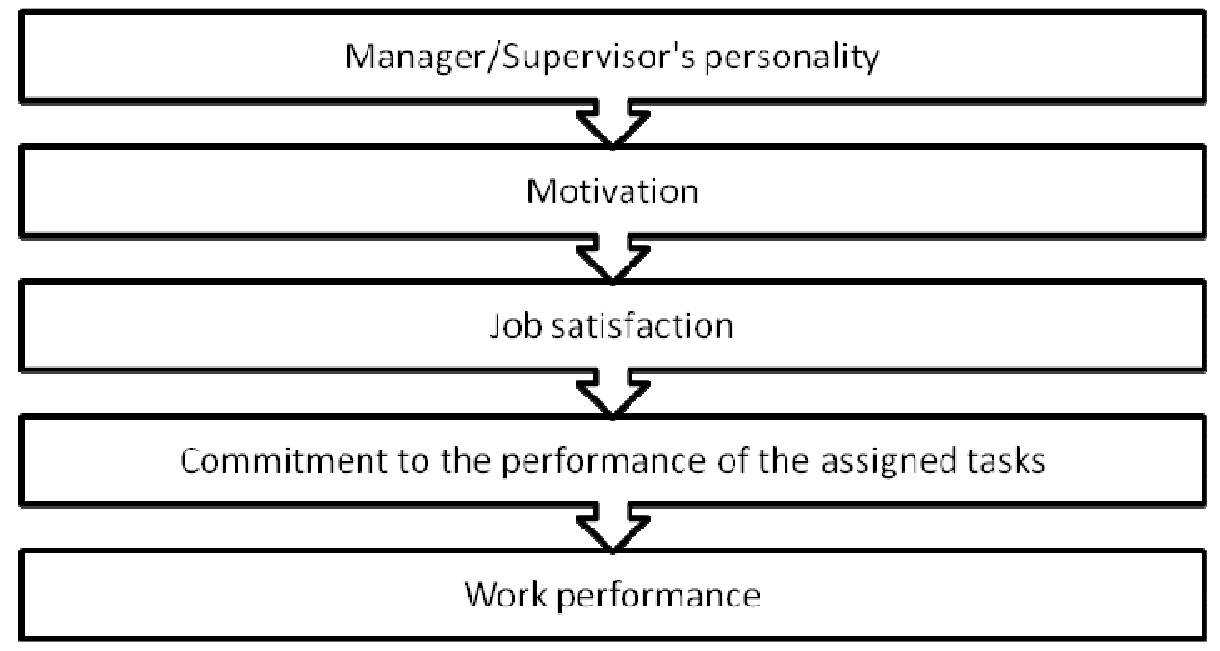

Fig. 4: Superior's personality and employee's work performance (own study)

The survey presented in this paper will be continued in other enterprises in order to confirm the model presented above.

Of course, the research is not without limitations. The survey was created on the basis of the authors' experience and found references. Some important factors could be omitted due to the subjectivity of the authors who looked at the problem from the engineer's point of view. The survey itself was quite long, so some respondents could feel bored and filled it up without any will or randomly. The research was conducted in cooperation with the management of the research enterprise, which could also have an impact on the results because the employees knew that the results would be available to the management so they could be afraid to answer freely and honestly.

\section{Acknowledgment}

"The project is financed by the Ministry of Science and Higher Education in Poland under the programme "Regional Initiative of Excellence" 2019 - 2022 project number 015/RID/2018/19 total funding amount 10721 040,00 PLN".

\section{References}

- Abuhashesh, M., Al-Dmour, R., Masa'deh, R. (2019), 'Factors that affect Employees Job Satisfaction and Performance to Increase Customers' Satisfactions,' Journal of Human Resources Management Research, 23, Article ID 354277, DOI: 10.5171/2019.354277.

- Amanchukwu, R.N., Stanley, G.J., and Ololube, N.P. (2015), 'A Review of Leadership Theories, Principles and Styles and Their Relevance to Educational Management.' Management 5 (1), 6-14.

- Armstrong, M. (2003), 'The role of firm size and performance pay in determining employee job satisfaction brief: firm size, performance pay, and job satisfaction,' Labour 22 (2), 315-43.

- Aziri, B. (2011), "Job satisfaction: a literature review,' Management Research And Practice, 3(4), 77-86.

- Bell, C. and Mjoli, T. (2013), 'The Effects of Participative Leadership on Organisational Commitment: Comparing Its Effects on Two Gender Groups among Bank Clerks,' African Journal of Business Management 8 (12), 451-459.

Manuela Ingaldi and Szymon Dziuba (2020), The Journal of Organizational Management Studies, DOI: 10.5171/2020.758804 
- $\quad$ Blake, R. and Mouton, J. (1964), The Managerial Grid: The Key to Leadership Excellence, Gulf Publishing Co, Houston.

- Blake, R.; Mouton, J. (1985), The Managerial Grid III: The Key to Leadership Excellence. Gulf Publishing Co, Houston.

- Bolden, R., Gosling, J., Marturano, A. and Dennison, P. (2003), Centre for Leadership Studies. University of Exeter, Exeter.

- Brahim, A.B., Riđić, O. and Jukić, T. (2015), 'The Effect of Transactional Leadership on Employees Performance - Case Study of 5 Algerian Banking Institutions,' Economic Review Journal of Economics and Business XIII (2), 7-20.

- Brenninger, H-J.F. (2015), Employee satisfaction and its impact on company value, Doctoral thesis. University of Latvia, Faculty of Economicsand Management, Riga.

- Bucurean, M. (2016), 'Comparative Analysis between the Managerial Style of Upper and Lower Level Managers,' Annals of the University of Oradea. Economic Science Series 1, [Online], [Retrieved November 24, 2003], http://web.a.ebscohost.com/ehost/pdf viewer/pdfviewer?vid= $0 \&$ sid=dc89cd2d-3ddd-4d59-9376fe23874bf24a\%40sessionmgr4007.

- Chaudhry, A.Q. and Javed, H. (2012), 'Impact of Transactional and Laissez Faire Leadership Style on Motivation,' International Journal of Business and Social Science 3 (7), 258-264.

- Cicero, L., Pierro, A. and van Knippenberg, D. (2007), 'Leader group prototypicality and job satisfaction: The moderating role of job stress and team identification,' Group Dynamics: Theory, Research, and Practice 11 (3), 165-175.

- Czerw, A. and Babiak, J. (2010), 'Transformacyjny styl kierowania w tworzeniu pozytywnej organizacji,' Zarządzanie Zasobami Ludzkimi 6, 5457.

- Dziuba S.T., Ingaldi M., Zhuravskaya M. (2020), 'Employees' Job Satisfaction and their Work Performance as Elements Influencing Work Safety,'
System Safety: Human - Technical Facility - Environment 2(1), 18-25, doi: 10.2478/czoto-2020-0003.

- Gastil, J. (1994), 'A Definition and Illustration of Democratic Leadership,' Human Relations 47 (8), 953-975.

- George, J.M. and Jones, G.R. (2008), Understanding and Managing Organizational behavior, Pearson/Prentice Hall, New Yersey.

- Gray, E.R. and Smeltzer, L.R. (1989), Management: The competitive edge, Macmillan Publishing Company, New York.

- Hair, J.F. Jr., Babin, B., Money, A.H., and Samouel, P. (2003), Essential of business research methods, John Wiley \& Sons, New Jersey.

- Heller, D. and Watson, D. (2005), 'The dynamic spillover of satisfaction between work andmarriage: The role of time, mood and personality,' Journal of Applied Psychology, 90(6), 12731279.

- $\quad$ Ilies, R., Wilson, K. S. and Wagner, D. T. (2009), 'The spillover of daily job satisfaction onto employees" family lives: The facilitating role of workfamily integration,' Academy of Management Journal, 52(1), 87-102.

- Ingaldi, M., and Dziuba, S.T. (2016), 'Supervisor's Assessment as an Element Effecting Technological Process in Chosen Metallurgical Company,' Proceedings of the 25th Anniversary International Conference on Metallurgy and Materials Metal2016, ISBN: 978-80-87294-67-3, 25-27 May 2016, Brno, Czech Republic, 1822-1828.

- Judge, T. A., Thoresen, C. J., Bono, J. E. and Patton, G.K. (2001), 'The job satisfaction-job performance relationship: A qualitative and quantitative review,' Psychological Bulletin, 127(3), 376-407, DOI: 10.1037/0033-2909.127.3.376.

- Kaliski, B.S. (2007), Encyclopedia of Business and Finance, Thompson Gale, Detroit, USA.

- $\quad$ Kirkpatick, S.A. and Locke, E.A. (1991), 'Leadership: do traits matter?, The executive 5(2): 48-60.

- Kondra, A.Z. and Hurst, D.C. (2009), 'Institutional processes of 
organizational culture,' Culture and Organization 15 (1), 39-58.

- Konstanciak, M., Borkowski, S. and Jagusiak, M. (2011), 'Supervisors' Assessment According to BOST Method in Chosen Polish Company,' Communications 4, 58-62.

- Kotus, M., Koloman, K. and Hudec, M. (2018), 'Assessment of Wood Processing Safety in the Production Organization.' Proceedings of the XV Internationl Conference MAPE 2018, Multidisciplinary Aspects of Production Engineering 1 (1), 727-737.

- Koys, D. (2001), 'The effects of employee satisfaction, organizational citizenship behavior, and turnover on organizational effectiveness: A unitlevel, longitudinal study,' Personnel psychology 54(1), 101-114.

- Koys, D. (2003), 'How the achievement of human resources goals drives restaurant performance,' Cornell Hotel and Restaurant Administration Quarterly, 44(1), 17-24.

- Kożusznik, B. (1985), Style kierowania. Uwarunkowania sytuacyjne i psychologiczne, Wyd. Uniwersytetu Śląskiego, Katowice.

- Lepold, A., Tanzer, N., Bregenzer, A. and Jiménez P. (2018), 'The Efficient Measurement of Job Satisfaction: Facet-Items versus Facet Scales,' International Journal of Environmental Research and Public Health, 15, 1362; doi:10.3390/ijerph15071362.

- $\quad$ Liker, J.K. (2003), The Toyota Way: 14 Management Principles from the World's Greatest Manufacturer, McGraw-Hill, New York.

- Likert, R. (1967), The human organization: Its management and value, McGraw-Hill, New York.

- Lumbasi, G.W., K'Aol, G.O. and Ouma, C.A. (2016), 'The Effect of Participative Leadership Style on the Performance of COYA Senior Managers in Kenya,' Researchjournali's Journal of Management 4 (5), 1-12.

- Madanchian, M., Hussein, N., Noordin, F. and Taherdoost, H. (2017), 'Leadership effectiveness measurement and its effect on organization outcomes,' Procedia
Engineering 181, 1043-1048. doi:10.1016/j.proeng.2017.02.50.

- Matthews, G., Deary, J.I. and Whiteman, M.C. (2003), Personality Traits, Cambridge University Press, Cambridge.

- Mielczarek, K. and Knop, K. (2018), 'Assessment of production processes functioning in the case of air bag production', MATEC Web of Conferences 183, 04009.

- Mintzberg, H. (1971), 'Managerial Work: Analysis from Observation,' Management Science 18 (2), B97-B110.

- Mroziewski, M. (2005), Style kierowania i zarządzania. Wybrane koncepcje, Difin, Warszawa.

- Murad Miah Md (2018), 'The impact of employee job satisfaction toward organizational performance: A study of private sector employees in Kuching, East Malaysia,' International Journal of Scientific and Research Publications 8(12), 207-278, DOI: 10.29322/IJSRP.8.12.2018.p8437.

- Oliviera, J.D., Oscrivao, E., Nagano, M.S., Ferraudo, A.S. and Rosim, D. (2015), 'What do small business ownermanagers do? A managerial work perspective,' Journal of Global Entrepreneurship Research 5 (19), 121.

- Ostroff, C. (199, 'The relationship between satisfaction, attitudes, and performance: An organizational level analysis.' Journal of Applied Psychology, 77(6), 963-974, DOI:10.1037/00219010.77.6.963.

- Parker, S.K., Morgeson, F.P. and Johns, G. (2017), 'One hundred years of work design research: Looking back and looking forward,' Journal of Applied Psychology, 102, 403-420.

- Ray, S. and Ray, I.A. (2012), 'Understanding Democratic Leadership: Some EY Issues and Perception with Reference to India's Freedom Movement,' Afro Asian Journal of Social Sciences 3 (3.1), 1-26.

- Raziq, A. and Maulabakhsh, R. (2015), Impact of Working Environment on Job Satisfaction,' Procedia Economics and Finance, 23, 717-725, DOI: 10.1016/S2212-5671(15)00524-9. 
- $\quad$ Sawczuk, D. and Kurowicka, E. (2018), 'Postrzeganie roli i kompetencji kierownika w aspekcie skutecznego zarządzania organizacją,' RynekSpołeczeństwo-Kultura 2(28), 140-145.

- Scanlan, J. N. and Still, M. (2013), 'Job satisfaction, burnout and turnover intention in occupational therapists working in mental health,' Australian Occupational Therapy Journal, 60, 310318. doi: 10.1111/1440-1630.1206).

- Shen, W.Y. and Zhu, J.W. (2012), 'Enterprise job satisfaction and turnover intention,' Social Scientist, 12, 80-83. doi: 10.3969/j.issn.10023240.2012.12.019.

- Shepherd, J.L. and Mathews, B.P. (2000), 'Employee commitment: academic vs practitioner perspectives', Employee Relations, 22(6), 555-575.

- Spector, B.A. (2015), 'Carlyle, Freud, and the Great Man Theory more fully considered,' Leadership 12(2), 250260, DOI: $10.1177 / 1742715015571392$.

- Spector, P. (1997), Satisfaction: Application, Assessment, Causes and Consequences, Sage, London.

- $\quad$ Springer, A. (2011), 'Wybrane czynniki kształtujące satysfakcję pracownika,' Problemy Zarzq̨dzania 9 (4(34)), 162180.

- $\quad$ Steinhardt, M., Dolbier, C., Gottlieb, N. and McCalister, K. (2003), 'The relationship between hardiness, supervisor support, group cohesion, and job stress as predictors of job satisfaction,' American Journal of Health Promotion 17, 382-389.

- $\quad$ Stoner, J.A.F., Freeman, R.E. and Gilbert, D.R. (1994), Management, Pearson Education.
- Tannenbaum, R. and Schmidt, W.H. (1958), 'How to choose a leadership pattern,' Harvard Business Review 36, 95-101.

- Ulewicz, R. (2013) 'Effectiveness assessment of functioning of quality assurance system,' Production Engineering Archives 1 (1), 38-40.

- Vallejo, R.D., Vallejo, J.A.D. and Parra, S.O. (2001), 'Job Satisfaction in Banking Workers,' Psicothema, 13, 4, 629-635.

- Vannucci, M.J., Whiteside, D.M., Saigal, S., Nichols, L. and Hileman, S. (2017), 'Predicting Supervision Outcomes: What is Different about Psychological Assessment Supervision?,' Australian Psychologist 52(2), 114-120.

- Wachowiak, P. (2001), Profesjonalny menedżer, Difin, Warszawa.

- Welch, J., and Welch, S. (2005), Winning, Harper Business, Ney York.

- Wyszkowska, Z., Jakubczak, A. and Doering, M. (2015), 'Styl kierowania a satysfakcja z życia zawodowego pracowników w małym przedsiębiorstwie produkcyjnym,' Prace Naukowe Akademii im. Jana Długosza w Częstochowie 9, 111-121.

- $\quad$ Yalabik, Y.Z., Popaitoon, P., Chowne, J.A. and Rayton, B.A. (2013), 'Work engagement as a mediator between employee attitudes and outcomes,' The International Journal of Human Resource Management 24, 2799-2823.

- Żuchowski, I. (2018), 'Style kierowania i relacje przełożony-podwładny w praktyce działalności przedsiębiorstw z subregionu ostrołęckiego i kierunki zmian w przyszłości,' Studia Ekonomiczne. Zeszyty Naukowe Uniwersytetu Ekonomicznego w Katowicach 357, 20-35. 